\title{
Financial Security in the Baltic States: Comparison with Selected EU Countries
}

\author{
Nadežda Semjonova \\ Riga Technical University
}

\begin{abstract}
The present paper applies recently developed consolidated indicator of the state financial security to the situation in Baltic States and some EU countries. The indicator summarises a number of economic and financial parameters relevant to the financial independence of the country. The resulting indicator demonstrates a reasonable correlation with sovereign Fitch rating both for Baltic States and the "old" EU countries, but Fitch rating gives more optimistic evaluation for old EU countries.
\end{abstract}

Keywords - Financial security, government debt, sovereign rating.

\section{INTRODUCTION}

A problem of the state financial system instability becomes the issue of primary concern due to the recent world financial crisis, demonstrating an urgent need for the instruments to evaluate the state financial stability in the aspect of the government debt policy and management.

One of the most important goals of the state fiscal policy development is the financial independence. In the framework of the present research, financial security is interpreted as proper arrangements of the state financial system that ensures financial stability, provides integrity of the public finances and neutralises threats to money stock, budget, taxes, and credits.

Following Furceri and Zdzienicka (2012), the impact of sovereign debt crises on the state economy is more severe due to banks or currency crises. Often, the banks / currency crises are directly or indirectly caused by the sovereign debt crisis because of excessive emission of the national currency (De Paoli, Hoggarth \& Saporta, 2006). Alongside, the unbalanced debt structure reduces financial stability of the state (De Broeck, 1997; Hughes, 1979; Drudi \& Giordano, 2000; Dooley, 2000; Afonso \& Jalles, 2013; European Central Bank, 2012; Moody's, 2012; Fitch Rating, 2012).

To evaluate the state financial stability, a number of internationally recognised agencies developed various credit ratings that became internationally recognised worldwide. Value of the rating, either high or low, always has noticeable political outcomes for the country under evaluation. Higher rating raises reputation of the country, hereby attracting foreign investments and opening better crediting opportunities.

The most important economic and financial indicators that contribute to the state sovereign ratings are GDP growth rate, consumer price index, GDP per capita, total government debt, external debt broken by particular economic sectors, state budget deficit / surplus, state balance of payments, foreignexchange reserves, etc. (Standard \& Poor's, 2012; Japan Credit Rating Agency, 2012; Oakley \& Hope, 2009; Ketners, Krastiņš,
\& Zvidrina, 2007). The political situation is also taken into account. Unfortunately, credit ratings sometimes provide inadequate, too optimistic evaluation of the actual situation in the country. Recent events posed some doubts on the ability of international credit ratings to predict potential government debt crises. Greece is the most illustrative example: just before the 2009 crisis, S\%P sovereign rating of this country was A, which was only five notches below the top triple A rating (Semjonova, 2014).

The previously developed methods of analysis of the state financial stability relied on various combinations of the state economic and financial parameters. For example, Ketners et al. proposed use of inflation rate, government payment balance, government debt to GDP ratio and money stock to GDP ratio (Ketners, Krastiňš, \& Zvidriņa, 2007). Still, this approach ignores several important indicators, such as the share of external debt. The latter seems to be an important factor in the development of the Greece financial crisis.

The author has recently developed the consolidated indicator for the evaluation of the state financial stability. This indicator has been applied to the Latvian situation in 2000-2012 (Eurostat, 2013). Results have demonstrated good correlation between the developed indicator and evaluations made by the leading international credit rating agencies.

The question whether this correlation remains in force for other countries still persists. In the scope of the present paper, the author has considered the Baltic countries as being similar in geographical, demographic, political and economic conditions. Alongside, some of the "old" European Union countries were considered as well.

\section{DATA AND METHODOLOGY}

According to N. Semjonova (2014), the consolidated indicator, developed to evaluate the state financial security, is based on the eight most important economic and financial parameters (Table I): The value of the government debt as a percent of GDP; the ratio of the debt service costs to the tax revenues; government budget deficit as a percent of GDP; inflation level; long-term interest rate of the government bonds; external government debt to the total government debt ratio; government debt per capita; money stock to GDP ratio. Some of these parameters were included in the Maastricht criteria as important indicators for country accession to the Eurozone.

The contribution of the each parameter to the consolidated indicator of the state financial stability was calculated as the ratio of the corresponding parameter to the critical "threshold" value (Table I). Partially these values were taken directly from 
the Maastricht criteria. For example, for the level of the government debt, the Maastricht criteria state that the threshold for the government debt to GDP ratio should be less than $60 \%$. The author used the same limit for the ratios "external to total debt" and "money stock to GDP". In the Maastricht approach, the inflation rate threshold and government bond long-term interest rate threshold were derived as an average of the three best indicators among the EU countries plus 1.5 percent points. For the considered time period, adding 1.5 percent points to the abovementioned indicators was nearly equal to the multiplication by the factor of two. Thus, by analogy, the threshold for the ratio "debt service costs to tax revenues" and for the debt per capita was calculated as the double average of the three best indicators in the EU. The thresholds for the selected parameters are summarised in Table I.

TABLE I

THE STATE FinANCIAL SECURITY INDICATORS

\begin{tabular}{|c|c|c|c|}
\hline No. & Indicator & & $\begin{array}{c}\text { Indicator } \\
\text { threshold }\end{array}$ \\
\hline 1 & Government debt / GDP & No more than & $60 \%$ \\
\hline 2 & $\begin{array}{c}\text { Interest (Government debt service } \\
\text { costs) / Tax revenues * }\end{array}$ & $* *$ & $\times 2$ \\
\hline 3 & $\begin{array}{c}\text { Government budget deficit / GDP } \\
\text { Inflation rate }\end{array}$ & $* *$ & +1.5 p.p. \\
\hline 5 & $\begin{array}{c}\text { Long-term interest rate of the } \\
\text { government bonds }\end{array}$ & $* *$ & +2 p.p. \\
\hline 6 & $\begin{array}{c}\text { External government debt / Total } \\
\text { government debt }\end{array}$ & 60 \\
\hline 7 & Government debt / Population & $* *$ & $\times 2$ \\
\hline 8 & Money stock (M2) / GDP & No less than & $60 \%$ \\
\hline
\end{tabular}

* Without social insurance contributions (earmarked revenues).

** Average from the three best parameter values in the EU.

The consolidated indicator for the evaluation of the state financial security was calculated as follows:

$$
X=\sum_{i=1}^{7} \frac{F_{i}}{R_{i}} \cdot \mu_{i}+\frac{R_{8}}{F_{8}} \cdot \mu_{8} \rightarrow \min ,
$$

where $F_{i}$ - an actual value of the particular parameter; $R_{i}-$ parameter threshold value; $i$ - parameter index in accordance with Table I; $\mu_{\mathrm{i}}$ - parameter weight factor, $\sum \mu_{i}=1$.

The value of the consolidated indicator $\mathrm{X}$ is equal to 1 when all parameters coincide with the corresponding thresholds. Improvement of the financial stability reduces the value of indicator.

N. Semjonova (2014) used the expert opinion analysis to obtain weight factors $\mu_{i}$ for each contributing parameter in (1). The expert pool included both academic staff and professionals employed in a number of state and private bodies with experience in the area of government debt politics and management. A total of 39 experts participated in the survey: 32 persons from academic personnel of the Latvian universities (Riga Technical University, University of Latvia, and Latvia University of Agriculture) and 7 professionals from Latvia, Spain, Slovakia, Slovenia and Switzerland ranged parameters from Table I in order of importance for the state financial security.

The inter-expert agreement was evaluated using Kendall's coefficient of concordance $W$ (Fuchs \& Gehring, 2013). The professional expert group demonstrated reasonable coincidence in opinion. At the same time, experts of academic pool felt apart into two groups, having different opinion. Therefore, three expert groups - one "professional" and two "academic" - were identified for further research. For each group, the ranks assigned by the experts were transformed into weights, summarised in Table II.

TABLE II

PARAMETER AVERAGE WEIGHTS BY EXPERT GROUPS

\begin{tabular}{|c|c|c|c|}
\hline Indicator & $\begin{array}{c}\text { 1st } \\
\text { academic } \\
\text { group }\end{array}$ & $\begin{array}{c}\text { 2nd } \\
\text { academic } \\
\text { group }\end{array}$ & Professionals \\
\hline Government debt / GDP & 0.223 & 0.224 & 0.214 \\
\hline Interest / Tax revenues & 0.121 & 0.188 & 0.173 \\
\hline Government budget deficit / GDP & 0.156 & 0.195 & 0.184 \\
\hline Inflation rate & 0.080 & 0.107 & 0.092 \\
\hline $\begin{array}{c}\text { Long-term interest rate of the } \\
\text { government bonds }\end{array}$ & 0.080 & 0.029 & 0.194 \\
\hline $\begin{array}{c}\text { External government debt / Total } \\
\text { government debt }\end{array}$ & 0.223 & 0.123 & 0.087 \\
\hline Government debt / Population & 0.018 & 0.091 & 0.020 \\
\hline Money stock (M2) / GDP & 0.098 & 0.042 & 0.036 \\
\hline
\end{tabular}

Differences in weights assigned by different expert groups are illustrated in Fig. 1. For example, experts-professionals treat government bond long-term interest rate as very important, while academicians practically neglect it. In turn, academic experts, perhaps, overestimate the role of the external debt to the total debt ratio.

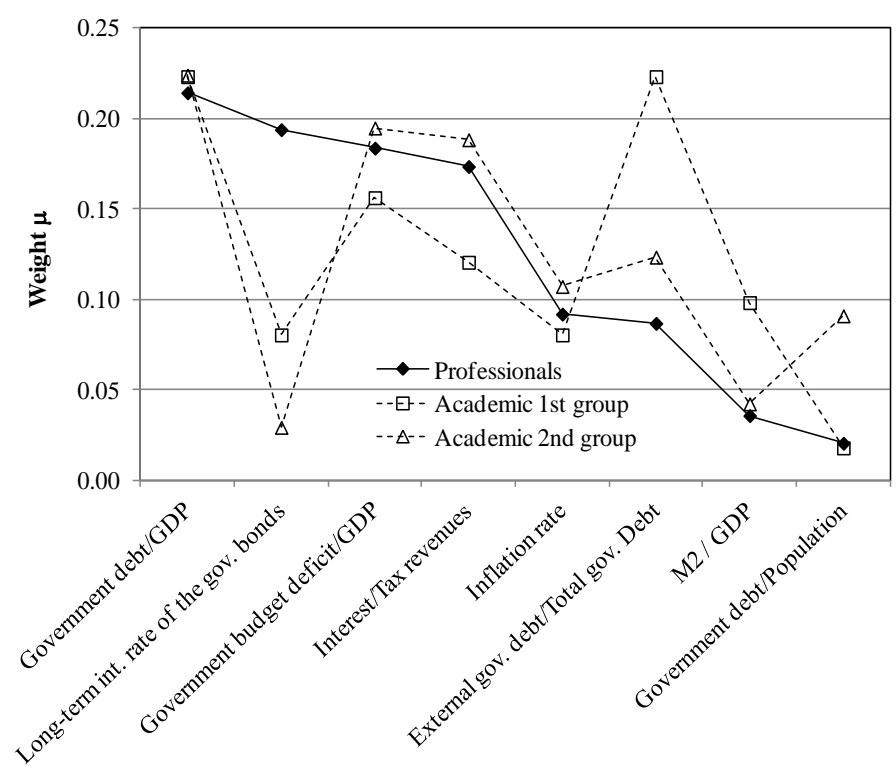

Fig. 1. Parameter weights by expert groups. 
Further in this paper, the $X$ indicator will be calculated using the weights obtained from three different expert pools.

The indicator was applied for the data of three Baltic countries over the period of 2000-2012. In addition, the number of "old" EU countries was selected for comparison: the United Kingdom, Belgium, Italy and Sweden. The selection of these countries has the following motivation: the United Kingdom was selected as one of the most developed world countries, Belgium is close to the Baltic countries in territory and population, Italia was chosen as the developed "problem" country, but Sweden - as the "old" EU country in the Nordic Baltic region. The data for all countries were extracted from the Eurostat database (European Security and Marked Authority, 2013).

The calculated $X$ indicator values were compared to Fitch sovereign ratings (Fitch Rating, 2012) assigned to the selected countries during the period under study. In order to perform the quantitative analysis, the original Fitch rating was substituted by numerical equivalent in a manner that value 0 corresponded to the lowest rating, but value 9.67 - to the highest rating.

\section{a) Latvia}

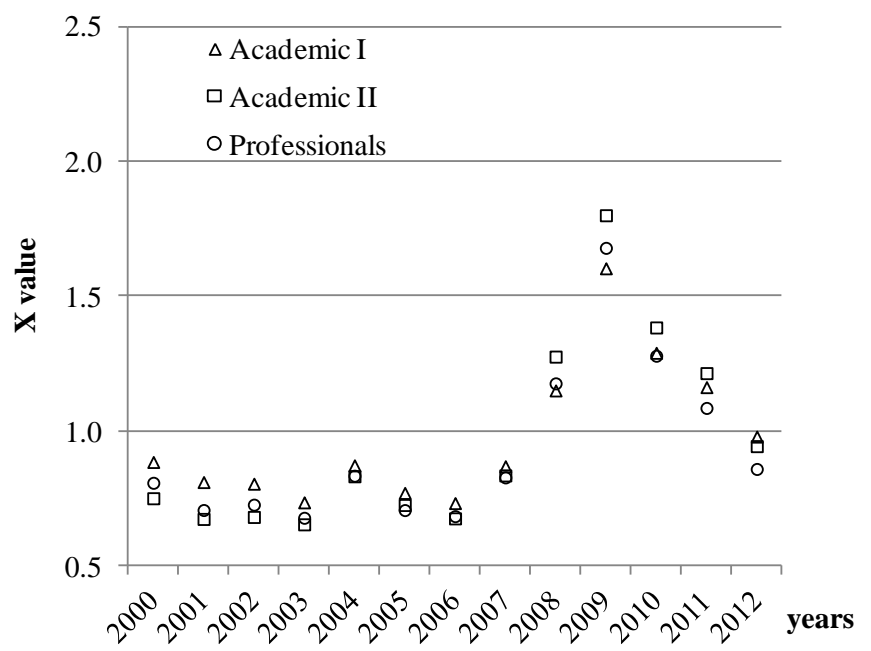

\section{RESULTS AND DISCUSSION}

Figure 2 demonstrates values of the $X$ indicator for the Baltic States calculated using weights, assigned by each expert group. Despite the noticeable difference in the weights assigned by different expert groups (Fig. 1), the resulting indicator values are close. Therefore, one can conclude that the result of evaluation of the financial stability using the proposed consolidated indicator does not depend much on the relative importance of the contributing parameters.

For all the Baltic States, indicator $X$ shows clear increment during the recession of 2008-2009. For Latvia, $X$ jumped nearly by 1 point, comparing with about 0.5 in Lithuania and only 0.2 in Estonia. Indeed, among all the Baltic countries Latvia faced most severe consequences of the recession. Nevertheless, the value of indicator in 2012 in Latvia was less than in Lithuania. This might indicate that Latvia more successfully overcame the crisis.

In turn, Estonia had the lowest values of $X$ indicators over the whole recession period, demonstrating the most sustainable financial policy among all the Baltic countries.

\section{b) Lithuania}

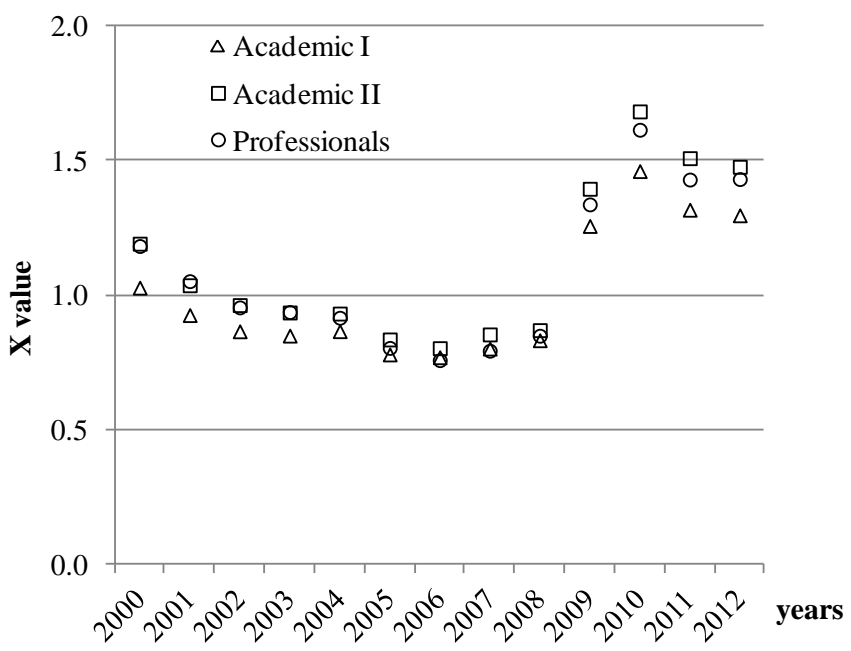

c) Estonia

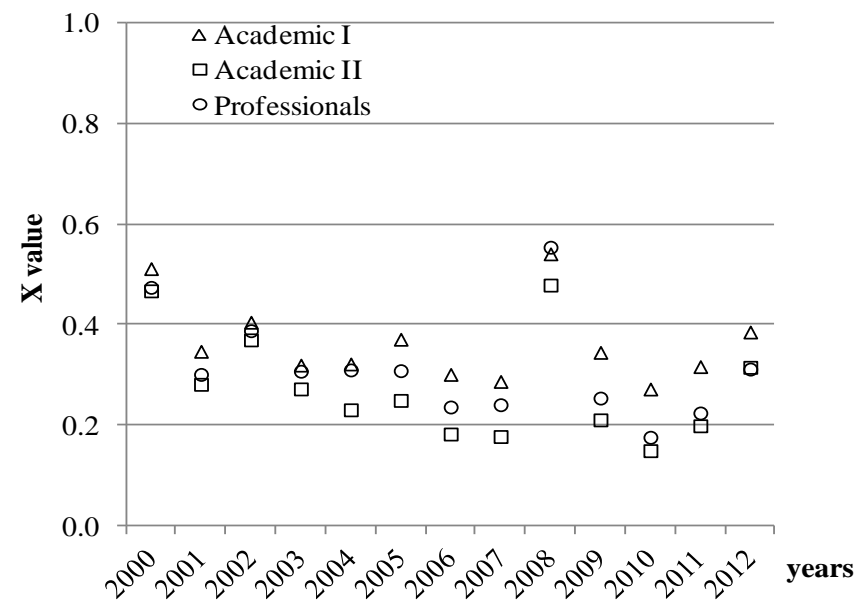

Fig. 2. Values of the consolidated indicator of the state financial stability for the Baltic States calculated using weight coefficients from different expert groups. 
The calculated values of $X$ for the selected EU countries are summarised in Fig. 3. For all selected countries, evaluation made by the second group of academic experts gives higher values of the indicator that corresponds to less stable financial situation.

In contrast to the case of the Baltic States, the indicator $X$ does not grew up much during the recession of 2008-2009. In Italy, $X$ demonstrates slight increment in the period

\section{a) United Kingdom}

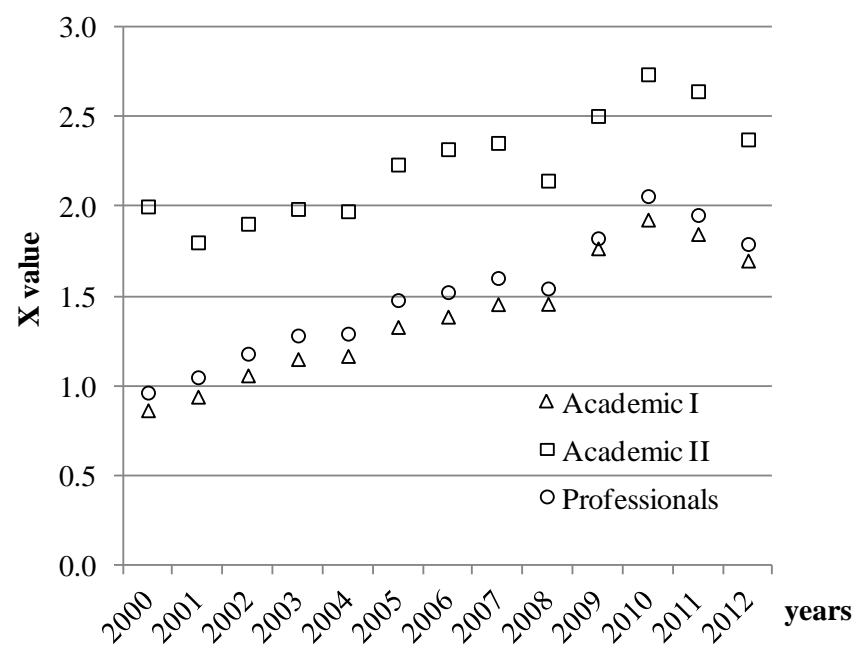

c) Italy

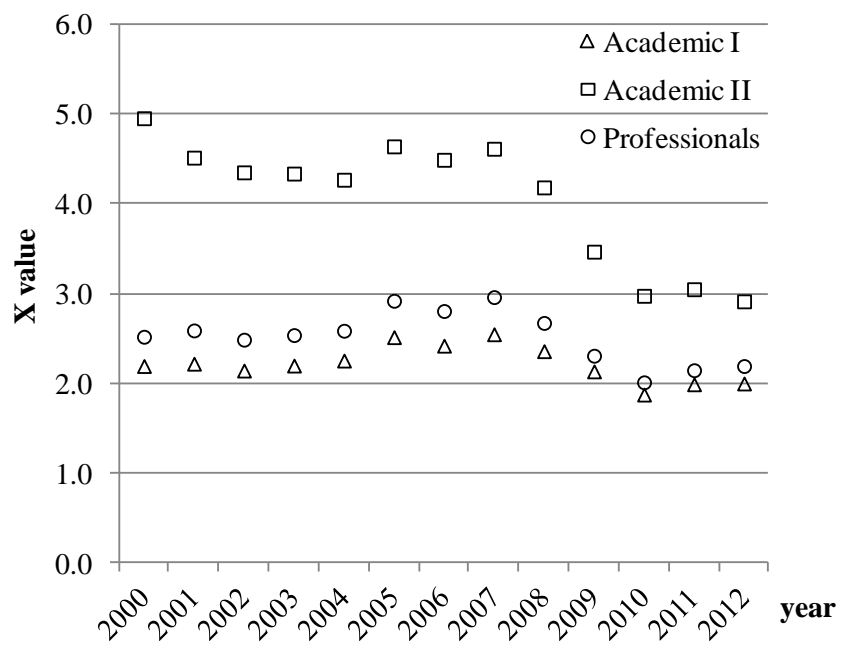

of 2005-2008 that could be related to the pre-crisis situation. Some increment was also observed in Belgium in 2005. There is a surprising decrease of $X$ in 2008 in the UK. Such a decrement may be explained by the relative nature of the indicator $X$ that becomes smaller for more successful countries as compared with the average EU level. For example, $X$ has steady been decreasing in Sweden since 2002.

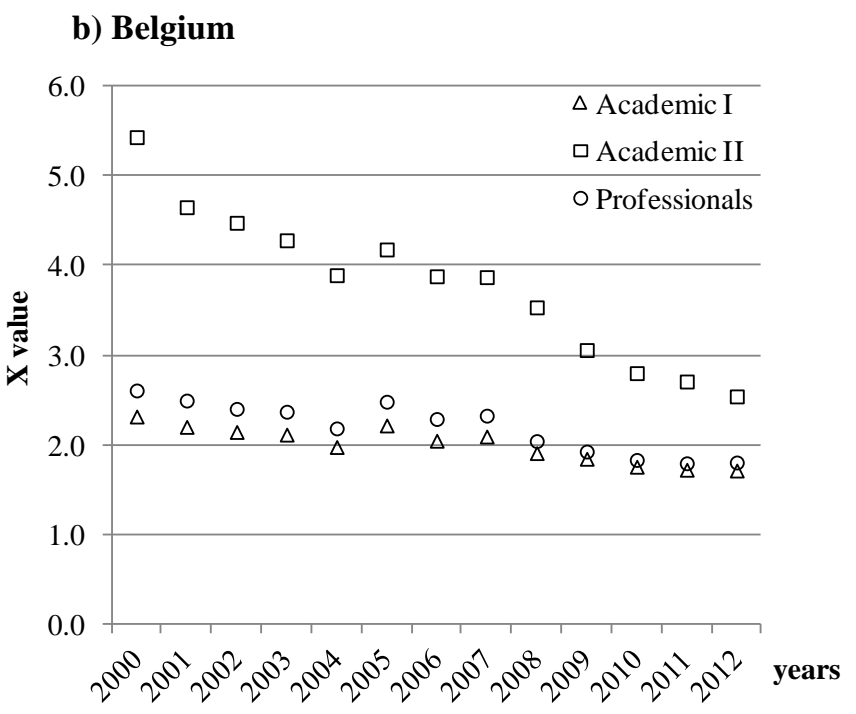

\section{d) Sweden}

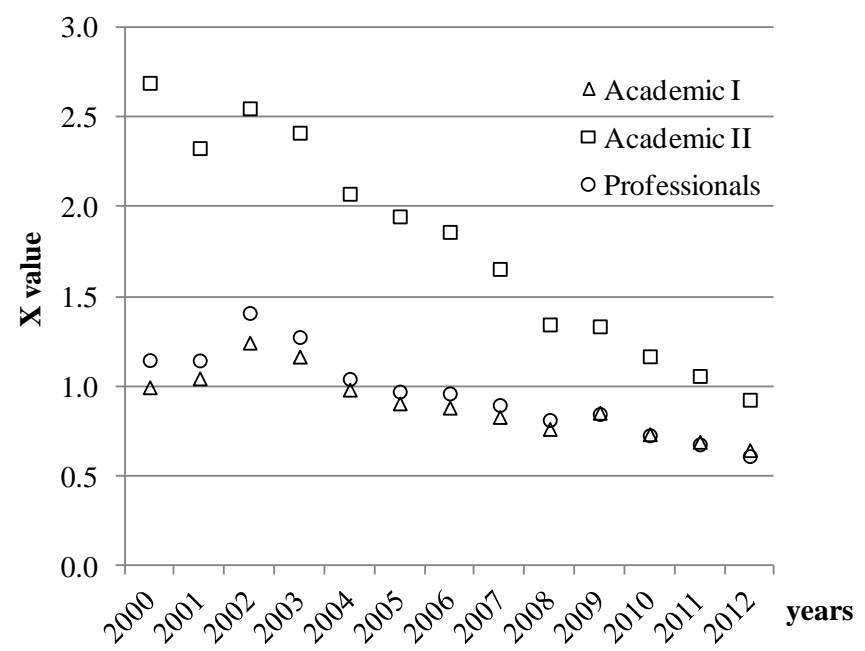

Fig. 3. Values of the consolidated indicator of the state financial stability for the selected EU countries calculated using weight coefficients from different expert groups.

Figure 4 shows correlation between the calculated $X$ indicator and sovereign credit rating assigned by Fitch agency. In the correlation diagram, the Baltic States and "old" EU countries form easy distinguishable sub-groups independently on which set of weights, either Academic I, Academic II or Professional was used for calculation of $X$. The Baltic States generally have lower Fitch rating; nevertheless, their values of $X$ indicator are smaller than the ones of "old" countries. Within each sub-group, there is significant negative correlation between $X$ and Fitch rating in each expert group (Table III). The correlation for "old" EU countries is significant despite the outlier that corresponds to low Fitch rating (7.67) of Italy in 2012.

The analysis of the government debt policy of Latvia and Lithuania demonstrated a noticeable increase in the level of the debt. For example, in Latvia the government debt to GDP increased from $19.8 \%$ in 2008 to $36.9 \%$ in 2009. In Lithuania, the government debt increased from $15.5 \%$ in 2008 to $29.3 \%$ in 2009. In turn, in Estonia for the same period the debt increased from $4.5 \%$ only to $7.2 \%$. Despite of such a high 
difference in the debt policy, the Fitch rating of all the Baltic States was close, so they fell within the same sub-group.

\section{TABLE III}

CORRELATION COEFFICIENTS BETWEEN $X$ AND FITCH RATING

\begin{tabular}{|c|c|c|c|}
\hline Group of countries & $\begin{array}{c}\text { 1st } \\
\text { academic } \\
\text { group }\end{array}$ & $\begin{array}{c}\text { 2nd } \\
\text { academic } \\
\text { group }\end{array}$ & Professionals \\
\hline Baltic States & -0.67 & -0.64 & -0.69 \\
\hline "Old" EU countries & -0.71 & -0.66 & -0.72 \\
\hline
\end{tabular}

For all correlation coefficients $P<1 \cdot 10^{-5}$.

There is even a more significant difference in debt policies within the sub-group of "old" EU countries. For instance, in Sweden, in the entire considered period, budget deficit does not exceeded $1 \%$ of GDP. Moreover, there were a number of years with the surplus, but the government debt decreased steadily from $50.5 \%$ in 2000 to $38.7 \%$ in 2012 . On the other hand, in the UK the debt jumped from $43.4 \%$ in 2008 to $67.3 \%$ in 2009 and continued to grow up to 2012. A similar situation was in Italy. Nevertheless, $X$ vs. Fitch rating scattering diagrams for these countries do not differ much from the ones of more "successful" countries.

Existence of separated sub-groups could imply some political or historical influence on the assignment of sovereign ratings that was already mentioned in both papers and mass media. Nevertheless, further research, involving more regions and countries, is required to confirm the insufficiency or bias in the rating assignments.

\section{Academic I}

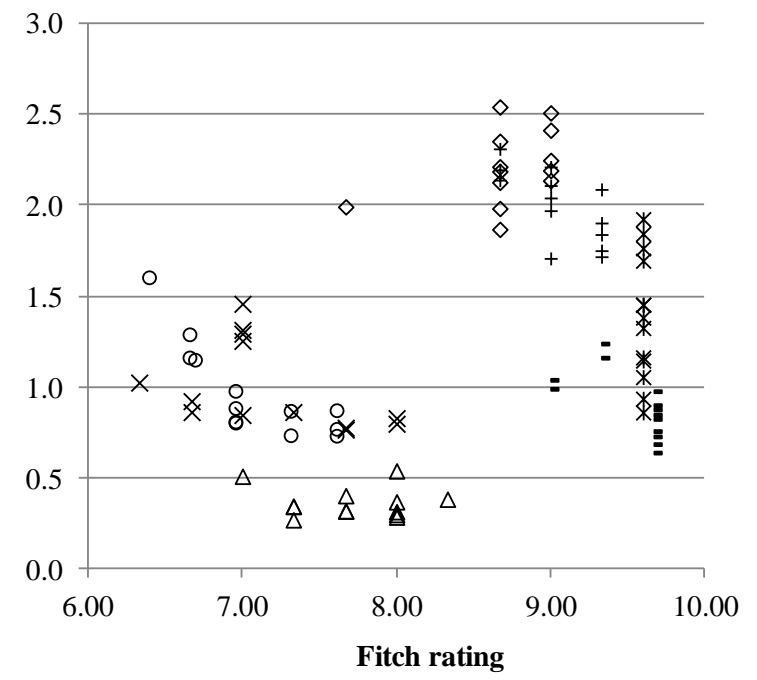

\section{Academic II}

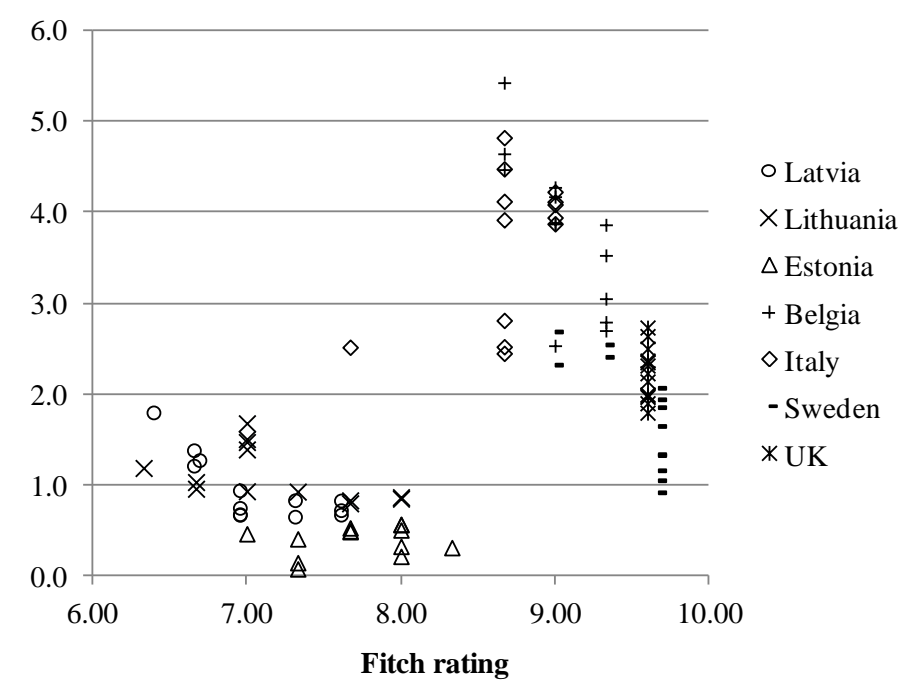

\section{Professionals}

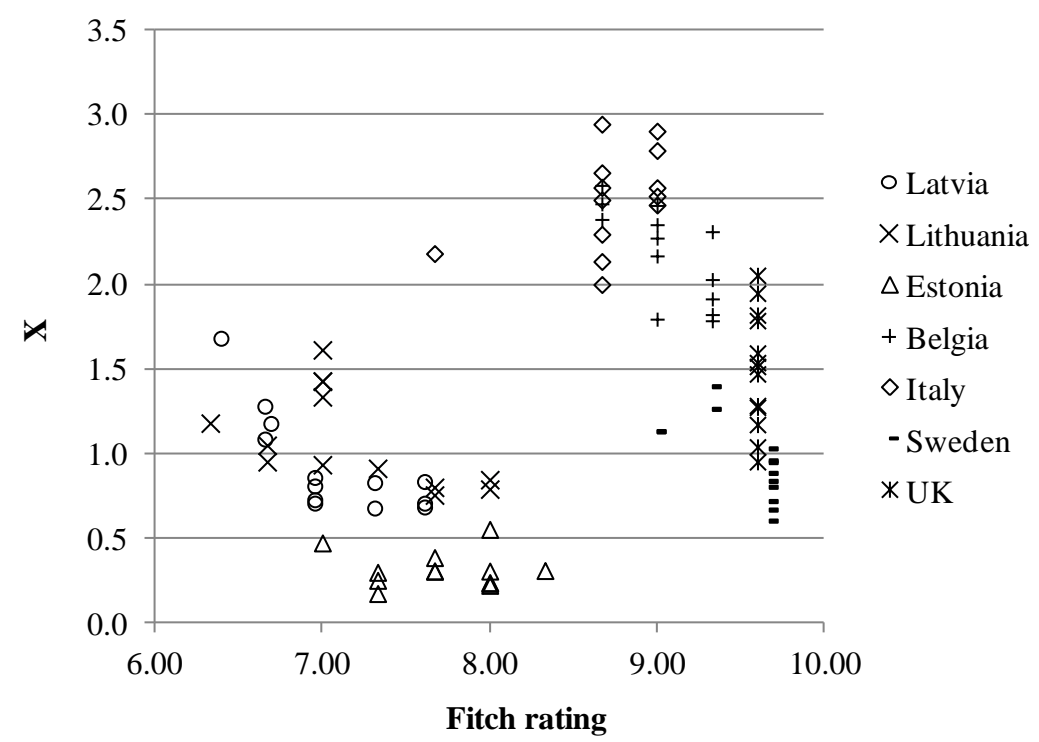

Fig. 4. Correlation between $X$ indicator calculated using weight coefficients from different expert groups and sovereign Fitch rating. 


\section{CONCLUSION}

The present paper has explored application of the consolidated indicator, based on the eight economic and financial parameters, for the evaluation of the state financial stability of the selected EU countries.

The indicator $X$, calculated for the Baltic States, correlates well with the sovereign rating assigned by the Fitch agency. Value of the indicator increased as the reaction to the recession of 2008-2009.

Similarly, there was significant correlation between values of $X$ and Fitch rating of "old" EU countries. Nevertheless, there was a noticeable difference in regularities $X$ vs. Fitch rating for the Baltic countries and "old" countries. Although their values of $X$ indicator are smaller, the Baltic States generally have lower Fitch rating that indicates a more stable situation. This may be evidence of some political or historical impact on the assignment of sovereign ratings.

For the further development of the indicator $X$, one should not use average EU data as the reference values because it reduces sensitivity of the indicator to the financial recession. Another important issue of the future research is the application of the indicator to the defaulted countries with the aim to evaluate its prognostic abilities.

\section{REFERENCES}

Afonso, A. \& Jalles, J. T. (2013). Growth and Productivity: The Role of Government Debt. International Review of Economics and Finance, 25, 384-398. Retrieved from http://pascal.iseg.utl.pt/ depeco/wp/wp132011.pdf

De Broeck, M. (1997). The financial structure of government debt in OECD countries: An examination of the time-consistency issue. Journal of Monetary Economics, 39(2), 279-301. http://dx.doi.org/10.1016/S0304-3932(97)00013-5

De Paoli, B. S., Hoggarth, G. \& Saporta, V. (2006). Costs of sovereign defaults. Bank of England. Financial Stability. No. 1, July.

Dooley, M. P. (2000). Debt management and crisis in developing countries. Journal of Development Economics, 63(1), 45-58. http://dx.doi.org/10.1016/S0304-3878(00)00099-7

Drudi, F. \& Giordano, R. (2000). Default risk and optimal debt management. Journal of Banking and Finance, 24(6), 861-891. http://dx.doi.org/10.1016/S0378-4266(99)00110-7
European Central Bank. (2012). Analysing government debt sustainability in the euro area. Monthly Bulletin, April 2012, 55-70, Retrieved from https://www.ecb.europa.eu/ pub/pdf/mobu/mb201204en.pdf

European Security and Marked Authority. (2013). Press release, ESMA/2013/1790. Retrieved September 5, 2015, from http://www.esma.europa.eu/

Eurostat. (2013). Database Government Deficit and Debt. Retrieved September 2, 2013, from http://epp.eurostat.ec.europa.eu/

Fitch Rating. (2012). Rating methodology. Retrieved August 13, 2012, from http://www.fitchratings.com/gws/en/sector/overview/sovereigns

Fuchs, A. \& Gehring, K. (2013). The Home Bias in Sovereign Ratings, Discussion Paper Series No. 552, University of Heidelberg, 54. Retrieved September 5, 2015, from http://www.uni-heidelberg.de

Furceri, D. \& Zdzienicka, A. (2012). How costly are debt crises? Journal of International Money and Finance, 31(4), 726-742. http://dx.doi.org/10.1016/j.jimonfin.2012.01.012

Japan Credit Rating Agency. (2012). Rating methodology. Retrieved August 18, 2012, from http://www.jcr.co.jp/english/

Hughes, H. (1979). Debt and development: The role of foreign capital in economic growth. World Development, 7(2), 95-112. http://dx.doi.org/10.1016/0305-750X(79)90026-3

Kendall, M. G. \& Babington, S. B. (1939). The Problem of $m$ Rankings. The Annals of Mathematical Statistics, 10(3), 275-287. http://dx.doi.org/10.1214/aoms/1177732186

Ketners, K., Krastiņš, A. \& Zvidriņa, S. (2007). Latvian Financial Policy Evaluation Principles and State Security Criteria. Economics and Business. Economy: Theory and Practice, 14, 34-42. (In Latvian: Ketners, K., Krastiņš, A., Zvidriṇa, S. (2007). Latvijas finanšu politikas novērtēšanas principi un valsts drošības kritēriji, Ekonomika un uzñēmējdarbība. Tautsaimniecība - teorija un prakse, 14, 34-42).

Moody's. (2012). Sovereign Bond Ratings, Rating Methodology. Retrieved July 14, 2012, from www.moodys.com/researchandratings/rating-methodologies

Oakley, D. \& Hope, K. (2009). Financial Times, January 14, 2009. Retrieved from www.ft.com.ft

Semjonova, N. (2014). Evaluation of the Latvian Financial Security: Aspects of Government Debt Policy. Safety of Technogenic Environment, 6, 36-42. http://dx.doi.org/10.7250/ste.2014.013

Standard \& Poor's. (2012). Sovereign ratings. Retrieved June 2, 2012, from www.standardandpoors.com/ratings/sovereigns/ratings

Nadežda Semjonova holds Dr. oec. degree and is an Assistant Professor at Riga Technical University, Faculty of Engineering Economics and Management.

Since 2010: RTU, Chair of Finances, Assistant Professor at a professional study programme; from 2007 to 2010: RTU, Chair of Management of Business and Human Resources, Assistant Professor at a professional study programme; from 1999 to 2007: RTU, Lecturer; from 1994 to 1998: The State Forest Service, State Inspection of Forest and Hunting, Chief Accountant-Auditor.

E-mail: Nadezda.Semjonova@rtu.lv 